\title{
Associations of FKBP5 polymorphisms and methylation and parenting style with depressive symptoms among Chinese adolescents
}

Lan Guo ${ }^{1,2+}$, Wanxin Wang ${ }^{1,2+}$, Yangfeng Guo ${ }^{3}$, Xueying Dư ${ }^{3}$ Guangduoji Shi ${ }^{1,2}$ and Ciyong Lu ${ }^{1,2^{*}}$

\begin{abstract}
Background: Genetic factors may interplay with environmental stressors to contribute to risks of depressive symptoms. This study aimed to investigate the association of FKBP5 polymorphisms and DNA methylation with depressive symptoms among Chinese adolescents, considering the role of parenting style.

Methods: This study used a nested case-control study design based on a cohort study, and the case $(n=120)$ and control groups $(n=118)$ were matched with age. Depressive symptoms, parenting style, and other demographics were measured. Fourteen potential polymorphisms and one promoter region in the FKBP5 gene were selected for genotyping and methylation analysis.

Results: In the adjusted models, a significant association between FKBP5 rs7757037 and depressive symptoms was found in the codominant model (AG vs. GG; adjusted odds ratio $[\mathrm{AOR}]=2.56,95 \% \mathrm{Cl}=1.13-5.78$ ) and dominant model (AA+AG vs. GG; $A O R=2.38,95 \% \mathrm{Cl}=1.11-5.120)$; rs 2817032 and rs 2817035 polymorphisms were associated with depressive symptoms in the codominant model and dominant model. Significant interactions between rs7757037 and the father's parenting style were found in the codominant model $(P=0.043)$ and dominant model $(P=0.043)$, but the gene-environment interactions were not significant after correcting for multiple testing. Moreover, the significant main effects of FKBP5 methylation status on depressive symptoms were not observed, and there was no significant interaction between FKBP5 methylation status and parenting style on depressive symptoms.
\end{abstract}

Conclusions: Further studies are required to confirm the effect of FKBP5 polymorphisms and methylation as well as their interactions with parenting styles in larger samples.

Keywords: FKBP5 polymorphism and methylation, Parenting style, Depressive symptoms, Chinese adolescents, Nested case-control study

\footnotetext{
* Correspondence: luciyong@mail.sysu.edu.cn

${ }^{\dagger}$ Lan Guo and Wanxin Wang contributed equally to this work.

'Department of Medical Statistics and Epidemiology, School of Public Health,

Sun Yat-sen University, 74 Zhongshan Rd 2, Guangzhou 510080, People's

Republic of China

${ }^{2}$ Guangdong Engineering Technology Research Center of Nutrition

Translation, Guangzhou 510080, People's Republic of China

Full list of author information is available at the end of the article
}

(C) The Author(s). 2021 Open Access This article is licensed under a Creative Commons Attribution 4.0 International License, which permits use, sharing, adaptation, distribution and reproduction in any medium or format, as long as you give appropriate credit to the original author(s) and the source, provide a link to the Creative Commons licence, and indicate if changes were made. The images or other third party material in this article are included in the article's Creative Commons licence, unless indicated otherwise in a credit line to the material. If material is not included in the article's Creative Commons licence and your intended use is not permitted by statutory regulation or exceeds the permitted use, you will need to obtain permission directly from the copyright holder. To view a copy of this licence, visit http://creativecommons.org/licenses/by/4.0/. The Creative Commons Public Domain Dedication waiver (http://creativecommons.org/publicdomain/zero/1.0/) applies to the data made available in this article, unless otherwise stated in a credit line to the data. 


\section{Background}

Depressive symptoms are one of the major mental health problems worldwide and are the main contributor to the global burden of disease in young people [1]. Adolescence represents a developmental transition period between childhood and adulthood, characterized by marked changes in biological systems and physical maturation of the body and brain, rendering adolescents vulnerable to mental health problems, including depressive symptoms [2]. However, the onset of depressive symptoms in adolescence has long-lasting effects on the adolescents' physical and brain development and may be a significant risk factor for clinical depression later, leading to serious social and educational impairments [3]. However, the pathological mechanism of depressive symptoms has not been adequately studied.

Evidence suggests that the dysregulated and dysfunctional stress response system (i.e., hypothalamicpituitary-adrenal (HPA) axis activity and glucocorticoid receptor (GR) sensitivity) has been one of the potential biological mechanisms of depression [4]. Meanwhile, the FK506 binding protein 51 (FKBP51) is the co-chaperone of heat shock protein (Hsp) 90 and GR, which can inhibit GR sensitivity to regulate the HPA axis and is highly expressed after stress exposure [5]. Then, the FKBP5 gene locating on chromosome 6p21.31 (GRCh38), which encodes FKBP51 protein, is an essential regulatory in the HPA stress regulation system [6].

Since the FKBP5 gene may be involved in the process of depressive symptoms development, a previous animal study has found a relevant role of the FKBP5 gene in modulating GR sensitivity and enhancing negative glucocorticoid feedback within the HPA axis through mice model lacking the FKBP5 gene (51KO mice) [7]. Human genetic studies have also reported significant associations between FKBP5 variants and depressive symptoms [8-11], although the results are inconsistent [12, 13]. For instance, Shimasaki et al. reported a positive association between rs1360780 and depressive state [14]; Scheuer et al. did not find any significant associations of the five FKBP5 single-nucleotide polymorphisms (SNPs) with the risk of depression, including rs1360780, rs3800373, rs9296158, rs9470080, and rs4713916) [15].

Moreover, besides genetics, DNA methylation is an epigenetic modification that regulates gene expression without changing the DNA sequence [16]. DNA methylation changes can affect gene expression related to the stress regulation system, which has been reported to play a vital role in the pathogenesis of mental disorders [17]. Prior evidence has shown that alteration in DNA methylation of the FKBP5 gene may be associated with mental disorders such as depression or depressive symptoms [18], which remains to be studied.
It has been widely reported that both genetic factors and environmental stressors play a role in the pathogenesis of depressive symptoms. A recent study showed the heritability of $40 \%$ for depression in a young adult cohort [19], suggesting genetic factors may interplay with environmental stressors to contribute to risks of depressive symptoms. Previous evidence suggests that the interactions between environmental stressors and FKBP5 rs3800373/ rs9296158/ rs1360780/ rs9470080 were statistically significant in a sample of clinically depressed adolescents [13], and the interaction effects of childhood physical abuse and FKBP5 rs3800373/ rs1360780/ rs4713916 on depressive symptoms in Chinese adolescents were significant [20]. There is evidence that DNA methylation of the FKBP5 gene is modified by external environmental factors [18]. Furthermore, it has been suggested that childhood trauma exposure interacts with the FKBP5 $\mathrm{T}$ allele could lead to reduced methylation in intron 7 of the FKBP5 gene, which may affect depressive symptoms [21].

Although adolescents may experience many environmental stressors, parenting style (referring to general patterns of parental behavior) is critically important for adolescent health [22], especially in a developmental period characterized by a rapid elevation in depressive symptoms. Based on the Baumrind's theory, negative parenting style (e.g., authoritarian or neglectful parenting style) can be categorized as a significant environmental stressor. Previous evidence also suggested that authoritarian and neglectful parenting styles were associated with higher depressive symptoms in adolescents [23, 24]. However, few studies considered the interaction effects between parenting style and FKBP5 SNPs on depressive symptoms, particularly among adolescents. Scarce studies examined the role of parenting style in influencing FKBP5 DNA methylation and depressive symptoms in adolescents. Therefore, the aims of this nested casecontrol study among Chinese adolescents were twofold, to investigate the association of FKBP5 genetic and epigenetic variation with depressive symptoms among Chinese adolescents and to investigate the potential role of parenting style on these associations.

\section{Methods}

\section{Study design and participants}

We used a nested case-control study design based on the Longitudinal Study of Adolescents' Mental and Behavioral well-being Research (LSAMBR) in Guangzhou, China (Registration No. ChiCTR1900022032). The LSAMBR is a prospective follow-up study, which adopted a multi-stage, stratified cluster, random sampling method to include 1957 students as eligible participants from nine high schools at baseline (response rate: 99.03\%) and followed up one year later (retention rate: 
93.8\%) $[25,26]$. Inclusion criteria of the LSAMBR were providing written informed consent; exclusion criteria included: 1) diagnosis of depressive disorder, severe psychiatric disorder, and/or alcohol or drug dependence disorder; 2) non-fluency in mandarin; 3) inability to understand questionnaires or provide consent for themselves. The self-reported questionnaires were distributed in the classrooms with the absence of teachers to protect the privacy of the students and reduce information bias. Based on the matched case-control study formula, the calculated sample size is 27 for each group when investigating the association between parenting style and depressive symptoms, including the parameters in the formula based on previously known parameters: alpha value $=0.05$, beta value $=0.20, P_{0}=0.176$ (the exposure rate of suffering adverse family care in the control group, $\mathrm{OR}=5.41$ ) [27]. The calculated sample size is 78 for each group when investigating the association between FKBP5 polymorphisms and depressive symptoms, including the parameters in the formula based on previously known evidence: alpha value $=0.05$, beta value $=$ $0.20, P_{0}=0.322$ (the exposure rate of carrying FKBP5 rs3800373 allele $\mathrm{C}$ in the control group), $\mathrm{OR}=1.39$ (A vs. C) [28]. In the current nested case-control study, students without depressive symptoms at baseline and follow-up were randomly selected as the control group $(n=118)$, and those with depressive symptoms at baseline and follow-up were treated as the case group $(n=$ 120). The case and control groups were matched with age (Fig. 1).

\section{Measures \\ Depressive symptoms}

Depressive symptoms were assessed by the Center for Epidemiologic Studies Depression Scale (CES-D) in Chinese. The Chinese version of this scale has been validated and widely utilized in Chinese studies [29], and shows satisfactory reliability (the total Cronbach's alpha $=0.88$ ) among Chinese adolescents [30]. The respondents were asked to rate the frequency of 20 symptoms of depression by selecting one of four response options ranging from 'rarely or none of the time' to 'most or all of the time'. The CES-D score ranges from 0 to 60 , with higher scores indicating more severe depressive symptomatology [31]. In this study, a score of 28 or higher was applied to identify students with depressive symptoms, and the cutoff score has been used in previous studies among Chinese adolescents [32, 33].

\section{Parenting style}

Parenting style was measured by asking students their perceptions of their father's and mother's parenting

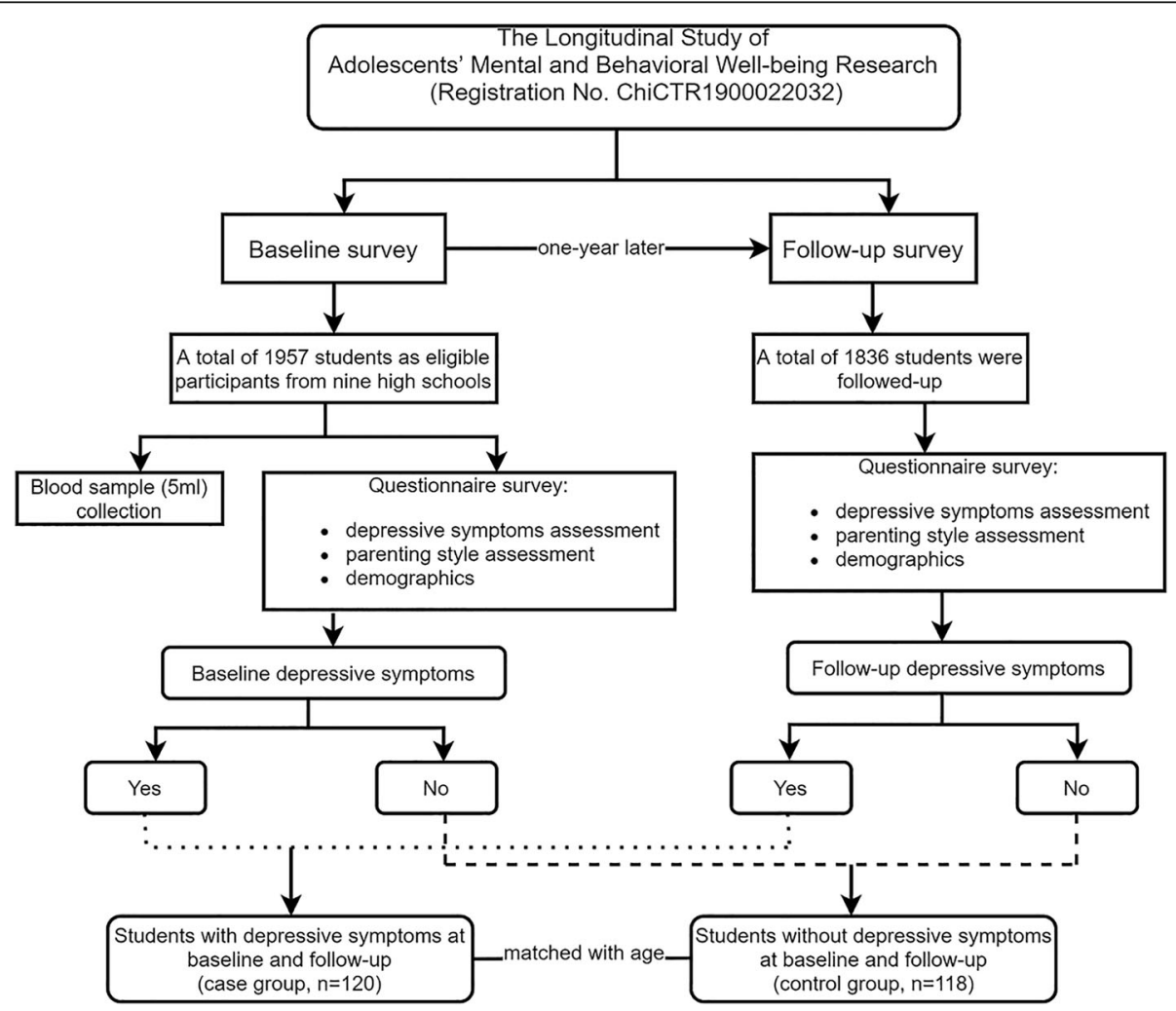

Fig. 1 The flowchart of the nested case-control study 
style. Based on the Baumrind's theory, the responses included four types of parenting styles $(1=$ Authoritative, $2=$ Authoritarian or disciplinarian, $3=$ Permissive or indulgent, $4=$ Neglectful or uninvolved) [34, 35]. Moreover, the explanations of different parenting styles have also been provided as below. Authoritative parenting means high demandingness and responsiveness; although authoritative parents have high expectations for achievement and maturity, they are also warm and responsive. Authoritarian parenting means high demandingness and low responsiveness; high levels of parental control and low levels of responsiveness are the main two characteristics of authoritarian parents. Permissive parenting means low demandingness and high responsiveness; permissive parents set very few rules and boundaries and are reluctant to enforce them. Neglectful parenting means low demandingness and low responsiveness, and neglectful parents are indifferent to their children's needs or uninvolved in their lives.

\section{Blood collection and DNA extraction}

A peripheral whole blood sample $(5 \mathrm{ml})$ was collected from each student using EDTA anticoagulant tubes at baseline survey (7:00 to $10: 00 \mathrm{am})$, and stored at $-80^{\circ} \mathrm{C}$ before use. After the follow-up survey was completed, genomic DNA was extracted from blood samples with the DNA extraction kit (BioTeke Corporation, Beijing, China) according to the manufacturer's instructions and prepared for genotyping and methylation analysis. DNA concentration was measured at the wavelength of A260 $\mathrm{nm}$ by a NanoDrop $2000 \mathrm{C}$ spectrophotometer (Thermo Scientific, Waltham, MA, USA).

\section{SNP selection and genotyping}

Haploview v.4.2 was used to select tagSNPs in linkage disequilibrium (LD) $\left(r^{2}>0.8\right)$ with the remaining SNPs at minor allele frequency (MAF) $>0.1$ in Han Chinese in Beijing (CHB). Functional SNP (rs3800373 and rs2817035) and SNPs most commonly associated with depressive symptoms or depressive disorder from the literature (rs7748266, rs9470080, rs4713902, rs1360780, rs9380524, rs9394309, rs7757037, rs1043805, rs2766533, rs4713916, rs9296158, rs2817032) [8-11] were prioritized as tagSNPs. In total, 14 SNPs were selected (Table S1). Assay Design 4.0 software (Agena Bioscience, Inc., San Diego, CA, USA) was used to design the primers. SNP genotyping was determined following the MassARRAY Nanodispenser (Agena Bioscience) protocols and MassARRAYiPLEX platform (Agena Bioscience) recommended by the manufacturer. None of the selected SNPs had more than $10 \%$ genotyping errors or were in severe Hardy-Weinberg disequilibrium $(P<0.001)$. Moreover, LD between the selected polymorphisms of the FKBP5 gene was examined by pair-wise comparisons of $\mathrm{D}^{\prime}$ and $\mathrm{r}^{2}$ using Haploview v.4.2. One LD block (consisting of the SNPs rs9380524, rs7748266, rs1360780, and rs4713902; $\left.r^{2}=0.08-0.79\right)$ were identified and presented in Fig. S1 (relatively low LD).

\section{FKBP5 promoter methylation analysis}

The CpG island in the promoter region of the FKBP5 gene was selected as the target for methylation analysis. The sequences of CpG island (chr6: 35728998$35,729,370)$ were determined through the CpG Island Online Prediction website (http://www.ebi.ac.uk/Tools/ seqstats/emboss_cpgplot/) based on the CpG island determination criteria (\%GC $>50$, length $>200 \mathrm{bp}$, Obs/Exp $\mathrm{CpG}>0.6$ ). The methylation of $14 \mathrm{CpG}$ units, encompassing $20 \mathrm{CpG}$ sites, was quantified using the SEQUENOM MassARRAY EpiTYPER platform [36]. Further quality control was performed, including excluding CpG units with less than $80 \%$ of available methylation data to ensure that spurious data were not analyzed [37]. Moreover, significantly deviating data points were also excluded [38]. A total of 14 CpG units were ultimately qualified for analysis (Table S2).

\section{Other information}

Demographic information including age, sex $(1=$ boy, 2 = girl), living arrangement was also collected. Living arrangement was assessed by asking who lived in the student's primary home (responses were coded as living with both parents $=1$, living with a single parent $=2$, living with others $=3$ ).

Morning serum cortisol level was also tested. Another 4-mL sample of whole blood was drawn from 7:00 to 10: $00 \mathrm{am}$ to obtain serum, and the morning serum total cortisol level was assayed with the competitive chemiluminescent microparticle immunoassay utilizing the $\mathrm{Ab}$ bott Architect i2000SR system (Abbott Laboratories, Abbott Park, IL).

\section{Statistical analysis}

All statistical analyses were conducted using SPSS (IBM SPSS Statistics for Windows, Version 22.0. Armonk, NY) and R (version 4.1.0, R Core Team, Vienna, Austria). All statistical tests were two-sided, and a $P$-value of $<0.05$ was considered statistically significant. Descriptive analyses were used to describe the sample characteristics. Continuous and categorical data were reported in the form of proportions and means (SD). Student $t$-tests for continuous variables and chi-square tests for categorical variables were conducted to test the differences between the cases and control groups. The distribution of the observed genotype frequencies of FKBP5 polymorphisms and FKBP5 methylation levels in the cases and control group was described, and multiple inheritance models were applied to analyze genotype data. The frequency 
and distribution of haplotypes in cases and controls were analyzed. Conditional logistic regression models were performed to first test the main effects of FKBP5 polymorphisms and parenting styles on depressive symptoms. The false discovery rate (FDR) was calculated to address the concern of multiple hypothesis testing and potential type I errors. The FDR-adjusted $P$ was indicated by " $q$ ", and the results were considered as nominally significant when $q<0.10$ [39]. To investigate interactions between $F K B P 5$ polymorphisms/methylation status and parenting styles on depressive symptoms, the interaction items between FKBP5 polymorphisms/ methylation status and the parenting style of father/ mother were added into the multivariate conditional logistic regression models along with single variables, respectively. To control potential type I errors, the twosided $\alpha$-level of 0.05 was corrected into $0.025(0.05 / 2$ for two-way interaction items of FKBP5 SNPs $\times$ the parenting style of father/mother).

\section{Results}

Table 1 shows the characteristics of the sample. In the students with depressive symptoms (cases), the median age was 13.0 (interquartile range: 13.0 to 15.0 ) years, the proportion of females was $66.7 \%$, and the proportion of students living with a single parent was $17.5 \%$. In the students without depressive symptoms (controls), the median age was 13.0 (interquartile range: 13.0 to 14.0) years, the proportion of females was $40.7 \%$, and the proportion of students living with a single parent was $8.5 \%$. The differences between the cases and control group in sex and living arrangement distribution were statistically significant $(P<0.05)$. Regarding the parenting style, the proportion of students who reported suffering authoritarian parenting style of the father in cases was $10.8 \%$ and in the control group was $3.4 \%$; the proportion of those who reported suffering authoritarian parenting style of the mother in cases was $10.0 \%$ and in the control group was 1.7\%; the differences of reported parenting style between the cases and control group were statistically significant $(P<0.05)$.

The genotype frequency distributions of the FKBP5 polymorphisms in the cases and control group are shown in Table S1. As shown in Table 2, without adjusting for other variables, only rs7757037, rs2817032, and rs2817035 were associated with depressive symptoms under the codominant model and dominant model (even after further correction for multiple testing, $q<$

Table 1 Sample characteristics between cases and control group

\begin{tabular}{|c|c|c|c|}
\hline Variable & $\begin{array}{l}\text { Non-depressive symptoms group } \\
(\mathrm{n}, \%)\end{array}$ & $\begin{array}{l}\text { Depressive symptoms group } \\
(\mathrm{n}, \%)\end{array}$ & $\begin{array}{l}P \\
\text { value* }\end{array}$ \\
\hline Total & $118(100)$ & $120(100)$ & \\
\hline Age, median (interquartile range), year & $13.0(13.0$ to 14.0$)$ & $13.0(13.0$ to 15.0$)$ & 0.118 \\
\hline \multicolumn{4}{|l|}{ Sex } \\
\hline Boy & $70(59.3)$ & $40(33.3)$ & \multirow[t]{2}{*}{$<0.001$} \\
\hline Girl & $48(40.7)$ & $80(66.7)$ & \\
\hline \multicolumn{4}{|l|}{ Living arrangement } \\
\hline Living with both parents & $103(88.0)$ & $86(71.7)$ & \multirow[t]{4}{*}{0.006} \\
\hline Living with a single parent & $10(8.5)$ & $21(17.5)$ & \\
\hline Living with others & $4(3.4)$ & $13(10.8)$ & \\
\hline Missing data & 1 & & \\
\hline $\begin{array}{l}\text { Morning serum total cortisol, median (interquartile range), } \\
\mathrm{nmol} / \mathrm{L}\end{array}$ & 224.8 (155 to 318$)$ & 197.6 (147.9 to 290.8) & 0.152 \\
\hline \multicolumn{4}{|l|}{ Parenting style of the father } \\
\hline Permissive & $81(68.6)$ & $67(55.8)$ & \multirow[t]{4}{*}{$<0.001$} \\
\hline Authoritative & $32(27.1)$ & $25(20.8)$ & \\
\hline Authoritarian & $4(3.4)$ & $13(10.8)$ & \\
\hline Neglectful & $1(0.8)$ & $15(12.5)$ & \\
\hline \multicolumn{4}{|l|}{ Parenting style of the mother } \\
\hline Permissive & $100(84.7)$ & $78(65.0)$ & \multirow[t]{4}{*}{0.001} \\
\hline Authoritative & $16(13.6)$ & $24(20.0)$ & \\
\hline Authoritarian & $2(1.7)$ & $12(10.0)$ & \\
\hline Neglectful & 0 & $6(5.0)$ & \\
\hline
\end{tabular}

*: The chi-square test was used for categorical variables, and the Wilcoxon rank test was used for age and morning serum total cortisol data 
Table 2 Main effects of the FKBP5 polymorphisms on depressive symptoms

\begin{tabular}{|c|c|c|c|c|c|c|c|c|c|c|c|c|c|}
\hline \multirow[t]{2}{*}{ Variable } & & \multicolumn{3}{|l|}{ Model 1} & \multicolumn{3}{|l|}{ Model 2} & \multicolumn{3}{|l|}{ Model 3} & \multicolumn{3}{|l|}{ Model 4} \\
\hline & & $\begin{array}{l}\text { OR }(95 \% \\
\mathrm{Cl})\end{array}$ & $\begin{array}{l}P \\
\text { value }\end{array}$ & $\begin{array}{l}q \\
\text { value }\end{array}$ & $\begin{array}{l}\text { Adjusted OR } \\
(95 \% \mathrm{Cl})\end{array}$ & $\begin{array}{l}P \\
\text { value }\end{array}$ & $\begin{array}{l}q \\
\text { value }\end{array}$ & $\begin{array}{l}\text { Adjusted OR } \\
(95 \% \mathrm{Cl})\end{array}$ & $\begin{array}{l}P \\
\text { value }\end{array}$ & $\begin{array}{l}q \\
\text { value }\end{array}$ & $\begin{array}{l}\text { Adjusted OR } \\
(95 \% \mathrm{Cl})\end{array}$ & $\begin{array}{l}P \\
\text { value }\end{array}$ & $\begin{array}{l}q \\
\text { value }\end{array}$ \\
\hline \multicolumn{14}{|l|}{ rs7757037 } \\
\hline \multirow[t]{2}{*}{$\begin{array}{l}\text { Codominant } \\
\text { model }\end{array}$} & $\begin{array}{l}\text { AA vs. } \\
\text { GG }\end{array}$ & $\begin{array}{l}2.01 \\
(0.94-4.34)\end{array}$ & 0.074 & 0.111 & $\begin{array}{l}2.17(0.93- \\
5.01)\end{array}$ & 0.072 & 0.108 & $\begin{array}{l}2.02(0.86- \\
4.78)\end{array}$ & 0.109 & 0.163 & $\begin{array}{l}1.98(0.85- \\
4.64)\end{array}$ & 0.116 & 0.174 \\
\hline & $\begin{array}{l}\text { AG vs. } \\
\text { GG }\end{array}$ & $\begin{array}{l}2.35 \\
(1.13-4.92)\end{array}$ & 0.023 & $0.075^{* *}$ & $\begin{array}{l}2.56(1.13- \\
5.78)\end{array}$ & 0.024 & $0.062^{* *}$ & $\begin{array}{l}2.34(1.02- \\
5.36)\end{array}$ & 0.044 & 0.115 & $\begin{array}{l}2.02(0.89- \\
4.63)\end{array}$ & 0.095 & 0.174 \\
\hline $\begin{array}{l}\text { Dominant } \\
\text { model }\end{array}$ & $\begin{array}{l}A A+A G \\
\text { vs. GG }\end{array}$ & $\begin{array}{l}2.20 \\
(1.10-4.39)\end{array}$ & 0.025 & $0.075^{* *}$ & $\begin{array}{l}2.38(1.11- \\
5.12)\end{array}$ & 0.026 & $0.062^{* *}$ & $\begin{array}{l}2.20(1.01- \\
4.78)\end{array}$ & 0.048 & 0.115 & $\begin{array}{l}2.00(0.93- \\
4.33)\end{array}$ & 0.077 & 0.174 \\
\hline $\begin{array}{l}\text { Recessive } \\
\text { model }\end{array}$ & $\begin{array}{l}A A \text { vs. } \\
A G+G G\end{array}$ & $\begin{array}{l}1.09 \\
(0.63-1.89)\end{array}$ & 0.748 & 0.748 & $\begin{array}{l}1.10(0.61- \\
2.00)\end{array}$ & 0.744 & 0.744 & $\begin{array}{l}1.10(0.60- \\
2.02)\end{array}$ & 0.762 & 0.762 & $\begin{array}{l}1.21(0.66- \\
2.23)\end{array}$ & 0.543 & 0.543 \\
\hline \multicolumn{14}{|l|}{ rs2817032* } \\
\hline \multirow[t]{2}{*}{$\begin{array}{l}\text { Codominant } \\
\text { model }\end{array}$} & Tा vs. CC & $\begin{array}{l}3.01 \\
(1.18-7.70)\end{array}$ & 0.022 & $0.075^{* *}$ & $\begin{array}{l}3.63(1.28- \\
10.25)\end{array}$ & 0.015 & $0.060^{* *}$ & $\begin{array}{l}3.12(1.09- \\
8.89)\end{array}$ & 0.034 & 0.115 & $\begin{array}{l}2.90(1.02- \\
8.27)\end{array}$ & 0.046 & 0.174 \\
\hline & $\begin{array}{l}\text { TC vs. } \\
\text { CC }\end{array}$ & $\begin{array}{l}2.77 \\
(1.04-7.35)\end{array}$ & 0.041 & $0.086^{* *}$ & $\begin{array}{l}4.01(1.35- \\
11.89)\end{array}$ & 0.012 & $0.060^{* *}$ & $\begin{array}{l}3.16(1.05- \\
9.55)\end{array}$ & 0.041 & 0.115 & $\begin{array}{l}3.09(1.03- \\
9.24)\end{array}$ & 0.044 & 0.174 \\
\hline $\begin{array}{l}\text { Dominant } \\
\text { model }\end{array}$ & $\begin{array}{l}T+T C \\
\text { vs. CC }\end{array}$ & $\begin{array}{l}2.91 \\
(1.17-7.27)\end{array}$ & 0.022 & $0.075^{* *}$ & $\begin{array}{l}3.76(1.36- \\
10.38)\end{array}$ & 0.011 & $0.060^{* *}$ & $\begin{array}{l}3.13(1.12- \\
8.74)\end{array}$ & 0.029 & 0.115 & $\begin{array}{l}2.97(1.07- \\
8.25)\end{array}$ & 0.037 & 0.174 \\
\hline $\begin{array}{l}\text { Recessive } \\
\text { model }\end{array}$ & $\begin{array}{l}\text { TT vs. } \\
\text { TC }+C C\end{array}$ & $\begin{array}{l}1.36 \\
(0.81-2.28)\end{array}$ & 0.243 & 0.265 & $\begin{array}{l}1.24(0.71- \\
2.15)\end{array}$ & 0.456 & 0.497 & $\begin{array}{l}1.29(0.73- \\
2.29)\end{array}$ & 0.385 & 0.420 & $\begin{array}{l}1.22(0.69- \\
2.16)\end{array}$ & 0.501 & 0.543 \\
\hline \multicolumn{14}{|l|}{ rs $2817035^{*}$} \\
\hline \multirow[t]{2}{*}{$\begin{array}{l}\text { Codominant } \\
\text { model }\end{array}$} & $\begin{array}{l}\text { GG vs. } \\
\text { AA }\end{array}$ & $\begin{array}{l}2.55 \\
(1.03-6.32)\end{array}$ & 0.043 & $0.086^{* *}$ & $\begin{array}{l}2.93(1.08- \\
7.96)\end{array}$ & 0.035 & $0.069^{* *}$ & $\begin{array}{l}2.49(0.90- \\
6.86)\end{array}$ & 0.079 & 0.158 & $\begin{array}{l}2.37(0.86- \\
6.54)\end{array}$ & 0.096 & 0.174 \\
\hline & $\begin{array}{l}\text { GA vs. } \\
\text { AA }\end{array}$ & $\begin{array}{l}2.07 \\
(0.80-5.37)\end{array}$ & 0.135 & 0.180 & $\begin{array}{l}2.52(0.88- \\
7.20)\end{array}$ & 0.085 & 0.113 & $\begin{array}{l}2.05(0.70- \\
5.99)\end{array}$ & 0.188 & 0.251 & $\begin{array}{l}2.03(0.70- \\
5.90)\end{array}$ & 0.194 & 0.259 \\
\hline $\begin{array}{l}\text { Dominant } \\
\text { model }\end{array}$ & $\begin{array}{l}\text { GG + GA } \\
\text { vs. AA }\end{array}$ & $\begin{array}{l}2.36 \\
(0.98-5.72)\end{array}$ & 0.056 & $0.096^{* *}$ & $\begin{array}{l}2.78(1.05- \\
7.36)\end{array}$ & 0.040 & $0.069^{* *}$ & $\begin{array}{l}2.32(0.86- \\
6.25)\end{array}$ & 0.095 & 0.163 & $\begin{array}{l}2.24(0.84- \\
6.02)\end{array}$ & 0.110 & 0.174 \\
\hline $\begin{array}{l}\text { Recessive } \\
\text { model }\end{array}$ & $\begin{array}{l}\text { GG vs. } \\
G A+A A\end{array}$ & $\begin{array}{l}1.47 \\
(0.87-2.47)\end{array}$ & 0.151 & 0.181 & $\begin{array}{l}1.45(0.83- \\
2.54)\end{array}$ & 0.197 & 0.236 & $\begin{array}{l}1.44(0.81- \\
2.57)\end{array}$ & 0.219 & 0.263 & $\begin{array}{l}1.38(0.77- \\
2.46)\end{array}$ & 0.275 & 0.330 \\
\hline \multicolumn{14}{|c|}{ Parenting style of the father } \\
\hline Authoritarian & & $\begin{array}{l}1.00 \\
\text { (reference) }\end{array}$ & & & $\begin{array}{l}1.00 \\
\text { (reference) }\end{array}$ & & & & & & & & \\
\hline Permissive & & $\begin{array}{l}0.26 \\
(0.08-0.82)\end{array}$ & 0.021 & NA & $\begin{array}{l}0.19(0.06- \\
0.66)\end{array}$ & 0.009 & NA & NA & NA & NA & NA & NA & NA \\
\hline Authoritative & & $\begin{array}{l}0.24 \\
(0.07-0.83)\end{array}$ & 0.024 & NA & $\begin{array}{l}0.22(0.06- \\
0.82)\end{array}$ & 0.023 & NA & NA & NA & NA & NA & NA & NA \\
\hline Neglectful & & $\begin{array}{l}4.62 \\
(0.46- \\
46.67)\end{array}$ & 0.195 & NA & $\begin{array}{l}3.15(0.29- \\
34.59)\end{array}$ & 0.348 & NA & NA & NA & NA & NA & NA & NA \\
\hline \multicolumn{14}{|c|}{ Parenting style of the mother } \\
\hline Authoritarian & & $\begin{array}{l}1.00 \\
\text { (reference) }\end{array}$ & & & $\begin{array}{l}1.00 \\
\text { (reference) }\end{array}$ & & & & & & & & \\
\hline Permissive & & $\begin{array}{l}0.13 \\
(0.03-0.60)\end{array}$ & 0.009 & NA & $\begin{array}{l}0.11(0.02- \\
0.53)\end{array}$ & 0.006 & NA & NA & NA & NA & NA & NA & NA \\
\hline Authoritative & & $\begin{array}{l}0.25 \\
(0.05-1.27)\end{array}$ & 0.095 & NA & $\begin{array}{l}0.22(0.04- \\
1.21)\end{array}$ & 0.081 & NA & NA & NA & NA & NA & NA & NA \\
\hline Neglectful & & NA & NA & NA & NA & NA & NA & NA & NA & NA & NA & NA & NA \\
\hline
\end{tabular}

Abbreviations: OR, odds ratio; $95 \% \mathrm{Cl}$, 95\% confidence interval; NA, not applicable or not available

*: Only the FKBP5 polymorphisms observed with a significant association of depressive symptoms in the unadjusted model were reported here Model 1: unadjusted models

Model 2: adjusted for age, gender, living arrangement, and morning cortisol level

Model 3: adjusted for age, gender, living arrangement, morning cortisol level, and parenting style of the father

Model 4: adjusted for age, gender, living arrangement, morning cortisol level, and parenting style of the mother

**: " $q$ value" indicates the FDR-adjusted $P$ value, and the results were considered as nominally significant when $q<0.10$ 
0.10). After adjusting for age, gender, living arrangement, and morning cortisol level, a significant association between rs7757037 and depressive symptoms was found in the codominant model (AG vs. GG; adjusted odds ratio $[\mathrm{AOR}]=2.56,95 \% \mathrm{CI}=1.13-5.78, q<0.10)$ and the dominant model (AA+AG vs. GG; $\mathrm{AOR}=2.38,95 \% \mathrm{CI}=$ $1.11-5.12, q<0.10)$; rs 2817032 polymorphism was associated with depressive symptoms in the codominant model (TT vs. CC; $\mathrm{AOR}=3.63,95 \% \mathrm{CI}=1.28-10.25$, $q<0.10 \&$ TC vs. CC; $\mathrm{AOR}=4.01,95 \% \mathrm{CI}=1.35-11.89$, $q<0.10)$ and dominant model (TT $+\mathrm{TC}$ vs. CC; AOR = $3.76,95 \% \mathrm{CI}=1.36-10.38, q<0.10)$; rs 2817035 was also associated with depressive symptoms in the codominant model (GG vs. AA; AOR $=2.93,95 \% \mathrm{CI}=1.08-7.96, q<$ $0.10)$ and dominant model $(\mathrm{GG}+\mathrm{GA}$ vs. AA, AOR $=$ $2.78,95 \% \mathrm{CI}=1.05-7.36, q<0.10)$. However, after further adjusting for the father's or mother's parenting style, there are no significant associations of rs7757037, rs2817032, and rs2817035 with depressive symptoms $(P>0.05$; after further correction for multiple testing, $q>0.10)$. Table $\mathbf{S} 2$ shows that the haplotype frequencies were not significantly different between the cases and the controls $(P>0.05)$.

Table 3 depicts the interaction effects between FKBP5 polymorphisms and parenting style on depressive symptoms. After adjusting for age, gender, living arrangement, and morning cortisol level, significant interactions between rs7757037 and the father's parenting style were found in the codominant model (AG vs. GG; $P=0.043$ ) and dominant model (AA+AG vs. GG; $P=0.043$ ). However, the gene-environment interactions were not significant after correcting for multiple testing.

As shown in Table S3, we observed no significant differences in the methylation levels of the selected FKBP5 CpG sites between the cases and the control group (all $P>0.05$ ). Additionally, there were no significant interactions between FKBP5 gene methylation status and parenting styles on depressive symptoms observed in this study (all $P>0.05$, Table 4 ).

\section{Discussion}

Considering that the stress-related gene FKBP5 may play a prominent role in depressive symptoms, this study investigated $F K B P 5$ polymorphisms and methylations as potential candidates for gene-environment influences on depressive symptoms in an adolescent sample. Our findings suggested that among the selected 14 SNPs, only FKBP5 rs7757037, rs2817032, and rs2817035 were associated with the increased risk of depressive symptoms in the codominant model and dominant model with and without adjusting for sociodemographic characteristics. Similarly, Piechaczek et al. reported that no main genetic effects of the five SNPs (rs3800373, rs9296158, rs1360780, rs9470080, and rs4713916) on depression were found [13]; Lou et al. reported that rs7757037 of FKBP5 was associated with depression in Chinese systemic lupus erythematosus patients [40] in dominant model. However, this finding was inconsistent with a study among patients with coronary artery disease, indicating rs2817032 was not associated with depressive symptoms among those patients [41]. The diversity of populations, which might result in various gene sensitivity, may explain the discrepancy of genotype models, while this study focused on Chinese adolescents.

Previous evidence has suggested that parenting style was one of the most significant environmental stressors influencing their child's growth [22]. Consistent with prior studies $[24,42]$, the protective role of the father's permissive and authoritative parenting style on the development of depressive symptoms among Chinese adolescents was observed. Moreover, this study found that the significant genetic main effects of FKBP5 rs7757037, rs2817032, and rs2817035 were not significant after adjusting for the parenting style of the father or mother, respectively. These findings were in line with most prior studies, which demonstrated no main genetic effects predicting case-control status after adjusting for other variables [12, 13, 15]; indicating that genetic factors may have to interact with environmental stressors to elicit depressive symptoms [19].

Considering that the FKBP5 gene plays a vital role in regulating the HPA-axis and is implicated in depressive symptoms [18], it seems appropriate to study the effect of the FKBP5 gene in the context of parenting style as an environmental stressor. Extending previous evidence, a novel aspect of this study was that the influences of the parenting style of father/mother (reflecting more stable living background) and their interactions with FKBP5 polymorphisms on adolescent depressive symptoms were explored. In contrast, much of the previous literature on the gene-environment interactions at the FKBP5 locus in the context of depressive symptoms mainly focused on adverse or traumatic life events [15, 20]. In this study, without adjusting for sociodemographic variables, significant interactions between FKBP5 rs7757037 and the father's parenting style were first observed in the codominant and dominant model, even correcting for multiple testing. These results might be explained by the diathesis-stress model of depressive symptoms [43], which indicated that FKBP5 rs7757037 carriers might exhibit a heightened HPA response activity and be more likely to be implicated in the risk for depressive symptoms when experiencing negative parenting styles. However, based on multiple testing corrections, these interaction effects did not significantly predict depressive symptoms after adjusting for sociodemographic variables. These interactions reached nominal significance, and the relatively small sample size in the 
Table 3 Interaction effects between FKBP5 polymorphisms and parenting style on depressive symptoms

\begin{tabular}{|c|c|c|c|c|c|}
\hline \multirow[t]{2}{*}{ Interaction item } & & \multicolumn{2}{|l|}{ Model 1} & \multicolumn{2}{|l|}{ Model 2} \\
\hline & & OR $(95 \% \mathrm{Cl})$ & $\overline{P \text { value }}$ & Adjusted OR $(95 \% \mathrm{Cl})$ & $P$ value \\
\hline \multicolumn{6}{|l|}{ rs7757037 } \\
\hline \multicolumn{6}{|c|}{ rs $7757037 \times$ parenting style of the father } \\
\hline \multirow[t]{2}{*}{ Codominant model } & AA vs. GG & $5.35(1.15-24.8)$ & 0.032 & $4.62(0.90-23.85)$ & 0.067 \\
\hline & AG vs. GG & $6.04(1.36-26.94)$ & $0.018^{*}$ & $5.13(1.05-25.06)$ & 0.043 \\
\hline Dominant model & $A A+A G$ vs. $G G$ & $5.78(1.34-24.96)$ & $0.019^{*}$ & $4.94(1.05-23.27)$ & 0.043 \\
\hline Recessive model & $A A$ vs. $A G+G G$ & $1.05(0.51-2.18)$ & 0.890 & $1.06(0.47-2.40)$ & 0.889 \\
\hline \multicolumn{6}{|c|}{ rs $7757037 \times$ parenting style of the mother } \\
\hline \multirow[t]{2}{*}{ Codominant model } & AA vs. GG & $0.70(0.11-4.43)$ & 0.702 & $0.22(0.03-1.65)$ & 0.139 \\
\hline & AG vs. GG & $0.72(0.12-4.21)$ & 0.715 & $0.26(0.04-1.75)$ & 0.165 \\
\hline Dominant model & $\mathrm{AA}+\mathrm{AG}$ vs. GG & $0.71(0.13-4.02)$ & 0.703 & $0.25(0.04-1.60)$ & 0.142 \\
\hline Recessive model & $A A$ vs. $A G+G G$ & $0.87(0.32-2.36)$ & 0.783 & $0.67(0.22-2.05)$ & 0.478 \\
\hline \multicolumn{6}{|l|}{ rs2817032 } \\
\hline \multicolumn{6}{|c|}{ rs $2817032 \times$ parenting style of the father } \\
\hline \multirow[t]{2}{*}{ Codominant model } & TT vs. CC & NA & NA & NA & NA \\
\hline & TC vs. CC & NA & NA & NA & NA \\
\hline Dominant model & $\pi+\mathrm{TC}$ vs. CC & NA & NA & NA & NA \\
\hline Recessive model & $\Pi$ Ts. TC $+C C$ & $1.10(0.56-2.15)$ & 0.784 & $1.04(0.49-2.21)$ & 0.912 \\
\hline \multicolumn{6}{|c|}{ rs $2817032 \times$ parenting style of the mother } \\
\hline \multirow[t]{2}{*}{ Codominant model } & TT vs. CC & NA & NA & NA & NA \\
\hline & TC vs. CC & NA & NA & NA & NA \\
\hline Dominant model & $T+\mathrm{TC}$ vs. CC & NA & NA & NA & NA \\
\hline Recessive model & TT vs. TC + CC & $0.98(0.37-2.57)$ & 0.969 & $0.61(0.21-1.79)$ & 0.372 \\
\hline \multicolumn{6}{|l|}{ rs2817035 } \\
\hline \multicolumn{6}{|c|}{ rs $2817035 \times$ parenting style of the father } \\
\hline \multirow[t]{2}{*}{ Codominant model } & GG vs. AA & $7.60(0.71-81.21)$ & 0.094 & $8.30(0.70-97.85)$ & 0.093 \\
\hline & GA vs. AA & $7.50(0.70-80.67)$ & 0.097 & $7.95(0.66-95.40)$ & 0.102 \\
\hline Dominant model & $G G+G A$ vs. AA & $7.43(0.71-77.64)$ & 0.094 & $8.14(0.71-93.65)$ & 0.093 \\
\hline Recessive model & GG vs. GA+AA & $1.10(0.56-2.14)$ & 0.787 & $1.15(0.54-2.45)$ & 0.714 \\
\hline \multicolumn{6}{|c|}{ rs $2817035 \times$ parenting style of the mother } \\
\hline \multirow[t]{2}{*}{ Codominant model } & GG vs. AA & NA & NA & NA & NA \\
\hline & GA vs. $A A$ & NA & NA & NA & NA \\
\hline Dominant model & $G G+G A$ vs. $A A$ & NA & NA & NA & NA \\
\hline Recessive model & $G G$ vs. $G A+A A$ & $1.19(0.46-3.05)$ & 0.722 & $0.90(0.32-2.58)$ & 0.850 \\
\hline
\end{tabular}

Abbreviations: OR, odds ratio; $95 \% \mathrm{Cl}, 95 \%$ confidence interval; NA, not applicable or not available Model 1: unadjusted models

Model 2: adjusted for age, gender, living arrangement, and morning cortisol level

*: Gene-environment interactions, which remained significant after correcting for multiple testing

present study needs to be considered. It would be significant to follow up on this finding in future studies using larger sample sizes. Besides, this finding may also reflect that a single environmental stressor (i.e., parenting style in this study) may not be potent enough to elicit depressive symptoms in adolescence, and other sociodemographic stressors may influence the effects of the single one environmental stress.
Additionally, FKBP5 epigenetic changes induced by environmental stressors may also be associated with the risk of depressive symptoms [44]. Considering parenting style may affect the developing brain through leading to changes in methylation levels of $F K B P 5$, this study also compared the difference of $F K B P 5$ methylation levels between students with and without depressive symptoms, and investigated the interactions between FKBP5 
Table 4 Interaction effects between FKBP5 gene methylation status and parenting style on depressive symptoms

\begin{tabular}{|c|c|}
\hline Interaction & $P$ value ${ }^{*}$ \\
\hline \multicolumn{2}{|c|}{ Parenting style of the father $x$} \\
\hline FKBP5-12 CpG 1 & 0.653 \\
\hline FKBP5-12 CpG 2 & 0.974 \\
\hline FKBP5-12 CpG 3 & 0.414 \\
\hline FKBP5-12 CpG 4 & 0.761 \\
\hline FKBP5-12 CpG 5.6.7 & 0.951 \\
\hline FKBP5-12 CpG 8 & 0.630 \\
\hline FKBP5-12 CpG 9 & 0.887 \\
\hline FKBP5-12 CpG 10.11 & 0.942 \\
\hline FKBP5-12 CpG 12 & 0.232 \\
\hline FKBP5-12 CpG 13 & 0.463 \\
\hline FKBP5-12 CpG 14 & 0.599 \\
\hline FKBP5-12 CpG 15 & 0.491 \\
\hline FKBP5-12 CpG 17.18.19 & 0.505 \\
\hline FKBP5-12 CpG 20 & 0.761 \\
\hline \multicolumn{2}{|c|}{ Parenting style of the motherx } \\
\hline FKBP5-12 CpG 1 & 0.951 \\
\hline FKBP5-12 CpG 2 & 0.661 \\
\hline FKBP5-12 CpG 3 & 0.575 \\
\hline FKBP5-12 CpG 4 & 0.211 \\
\hline FKBP5-12 CpG 5.6.7 & 0.230 \\
\hline FKBP5-12 CpG 8 & 0.217 \\
\hline FKBP5-12 CpG 9 & 0.852 \\
\hline FKBP5-12 CpG 10.11 & 0.818 \\
\hline FKBP5-12 CpG 12 & 0.063 \\
\hline FKBP5-12 CpG 13 & 0.205 \\
\hline FKBP5-12 CpG 14 & 0.486 \\
\hline FKBP5-12 CpG 15 & 0.498 \\
\hline FKBP5-12 CpG 17.18 .19 & 0.766 \\
\hline FKBP5-12 CpG 20 & 0.211 \\
\hline
\end{tabular}

*: The interaction items between FKBP5 methylation status and the parenting style of father/mother were added into the multivariate conditional logistic regression models along with single variables, respectively. Considering the $95 \%$ confidence intervals of the odds ratios were too wide, only $P$ values were reported

methylation status and parenting style. However, no significant findings were observed. Similarly, Klinger-König et al. reported there were no significant effects of FKBP5 methylation or the interaction between FKBP5 methylation and childhood maltreatment on depressive symptoms [45]. Höhne et al. showed that no significant difference of FKBP5 DNA methylation in intron 7 between subjects with a lifetime history of depression and healthy controls was observed [46]. Bustamante et al. also reportedly did not observe any association of FKBP5 methylation levels in intron 7 or intron 2 with depressive symptoms [47]. These results might be related to the complex relationship between parenting style, FKBP5 methylation, and depressive symptoms, highlighting that multiple factors may contribute to the development of depressive symptoms following exposure to different parenting styles. Moreover, parenting style exposures have been shown to be long-lasting, and they may not only influence depressive symptoms through the FKBP5 methylation pathway.

To our knowledge, the present study is the first nested case-control study to explore the associations of FKBP5 genetic and epigenetic variation with depressive symptoms among Chinese adolescents in the context of parenting style. However, several limitations should be noted. First, only the FKBP5 gene was examined in this study by a hypothesis-driven approach. Considering this study only focused on the effects of the FKBP5 gene, other potential genes with implications in depressive symptoms (e.g., $B D N F$ or NR3C1 gene) were not considered, and we would like to explore the effects of other genes on depressive symptoms in our future study. Second, although parenting style and depressive symptoms were measured by self-reported, which may lead to selfreport bias, self-reports remain a common and accepted method. Third, considering the questionnaire length, parenting style was not assessed by the scales like the Egna Minnen Beträffande Uppfostran (EMBU) in this study, then the lack of evaluating psychometric properties for the parenting style measure in this study may be a limitation. Fourth, although previous studies have used a similar sample size to explore the associations between the FKBP5 gene and depressive symptoms or depression $[45,47]$, the sample size in the present study is relatively small, which may imply insufficient statistical power these findings.

\section{Conclusions}

This study suggests significant relationships of FKBP5 rs7757037, rs2817032, and rs2817035 with depressive symptoms without adjusting for parenting style and observes a nominally significant interaction between FKBP5 rs7757037 and parenting style of the father on depressive symptoms. However, there was no significant association between FKBP5 CpG methylation status and the interactions between FKBP5 CpG methylation and parenting style with depressive symptoms. Therefore, this work suggests that parenting style, almost experiencing by each adolescent, can be targeted in prevention strategies, and a particular focus should be placed on adolescents who suffer negative parenting styles. Moreover, this study also indicates that FKBP5 variation, not DNA methylation, may be more sensitive in moderating the effects of parenting style stressors on depressive symptoms, especially for the negative parenting style of the 
father, even though the evidence under the mechanism is deficient now. Further studies to investigate the underlying mechanism are warranted.

\section{Supplementary Information}

The online version contains supplementary material available at https://doi. org/10.1186/s12888-021-03576-6.

Additional file 1 Table S1. Genotype frequency distribution of the FKBP5 polymorphisms between students with and without depressive symptoms. Fig. S1. The linkage disequilibrium plots for the SNPs in FKBP5. D' is a measure of linkage disequilibrium between two genetic markers. A value of $D^{\prime}=1$ (complete LD) indicates that SNPs have not been separated by recombination, while values of $D^{\prime}<1$ (incomplete LD) indicate that the ancestral LD was disrupted during the history of the population. The $r^{2}$ is a measure of linkage disequilibrium between two genetic markers. For SNPS that have not been separated by recombination or have the same allele frequencies (perfect LD), $r^{2}=1$. Table S2. Haplotypes of FKBP5 gene and depressive symptoms. Table S3. Methylation levels at CpG sites in the promoter region of FKBP5 between students with and without depressive symptoms

\section{Acknowledgements}

The authors gratefully acknowledge the contribution of participating schools, and also gratefully acknowledge technical support from the School of Public Health, Sun Yat-sen University.

\section{Authors' contributors}

Lan Guo and Ciyong Lu designed the study. Lan Guo, Wanxin Wang, Yangfeng Guo, Xueying Du, and Guangduoji Shi managed the literature searches and summaries of previous related work. Xueying Du, Wanxin Wang, Yangfeng Guo, and Guangduoji Shi carried out the field research. Lan Guo did the statistical analyses and wrote the first draft of this manuscript. All authors reviewed the manuscript.

\section{Funding}

This work was supported by National Natural Science Foundation of China (grant No. 81761128030; grant No. 81903339), Natural Science Foundation of Guangdong Province (grant No. 2019A1515011091), and the Science and Technology Planning Project of Guangzhou (grant No. 202102020136).

\section{Availability of data and materials}

The datasets used and/or analyzed during the current study are available from the corresponding author on reasonable request.

\section{Declarations}

\section{Ethical approval and consent to participate}

The study procedures were carried out in accordance with the Declaration of Helsinki. The study obtained ethical approval from the Sun Yat-sen University, School of Public Health Institutional Review Board (Ethics Number:

L2017060). All participants and their legal guardians were informed in detail about the design and aims of the study and gave written assent to participate in the study, and written informed consent was obtained from each participant and one of the student's legal guardians.

\section{Consent for publication}

Not applicable.

\section{Competing interests}

The authors declare no conflict of interest.

\section{Author details}

${ }^{1}$ Department of Medical Statistics and Epidemiology, School of Public Health, Sun Yat-sen University, 74 Zhongshan Rd 2, Guangzhou 510080, People's Republic of China. ${ }^{2}$ Guangdong Engineering Technology Research Center of Nutrition Translation, Guangzhou 510080, People's Republic of China. ${ }^{3}$ Health Promotion Centre for Primary and Secondary Schools of Guangzhou Municipality, Guangzhou 510080, China.
Received: 17 July 2021 Accepted: 1 November 2021

Published online: 09 November 2021

\section{References}

1. Erskine HE, Moffitt TE, Copeland WE, Costello EJ, Ferrari AJ, Patton G, et al. A heavy burden on young minds: the global burden of mental and substance use disorders in children and youth. Psychol Med. 2015;45(7):1551-63. https://doi.org/10.1017/S0033291714002888.

2. National Academies of Sciences, Engineering, and Medicine; Health and MedicineDivision; Division of Behavioral and Social Sciences and Education; Board on Children, Youth, and Families; Committee on the Neurobiological and Socio-behavioral Science of Adolescent Development and Its Applications; Backes EP, Bonnie RJ, editors. The Promise of Adolescence: Realizing Opportunity for All Youth. Washington (DC): National Academies Press (US); 2019. Adolescent Development. Available from: https://www. ncbi.nlm.nih.gov/books/NBK545476/.

3. Thapar A, Collishaw S, Pine DS, Thapar AK. Depression in adolescence. Lancet. 2012;379(9820):1056-67. https://doi.org/10.1016/S0140-6736(11 )60871-4.

4. van Bodegom M, Homberg JR, Henckens M. Modulation of the hypothalamic-pituitary-adrenal Axis by early life stress exposure. Front Cell Neurosci. 2017;11:87. https://doi.org/10.3389/fncel.2017.00087.

5. Zannas AS, Binder EB. Gene-environment interactions at the FKBP5 locus: sensitive periods, mechanisms and pleiotropism. Genes Brain Behav. 2014; 13(1):25-37. https://doi.org/10.1111/gbb.12104.

6. Cheng R, Juo SH, Loth JE, Nee J, lossifov I, Blumenthal R, et al. Genomewide linkage scan in a large bipolar disorder sample from the National Institute of Mental Health genetics initiative suggests putative loci for bipolar disorder, psychosis, suicide, and panic disorder. Mol Psychiatry. 2006; 11(3):252-60. https://doi.org/10.1038/sj.mp.4001778.

7. Hartmann J, Wagner KV, Liebl C, Scharf SH, Wang XD, Wolf M, et al. The involvement of FK506-binding protein 51 (FKBP5) in the behavioral and neuroendocrine effects of chronic social defeat stress. Neuropharmacology. 2012;62(1):332-9. https://doi.org/10.1016/j.neuropharm.2011.07.041.

8. Szczepankiewicz A, Leszczynska-Rodziewicz A, Pawlak J, Narozna B, Rajewska-Rager A, Wilkosc M, et al. FKBP5 polymorphism is associated with major depression but not with bipolar disorder. J Affect Disord. 2014;164: 33-7. https://doi.org/10.1016/j.jad.2014.04.002.

9. Tozzi L, Carballedo A, Wetterling F, McCarthy H, O'Keane V, Gill M, et al. Single-nucleotide polymorphism of the FKBP5 gene and Childhood maltreatment as predictors of structural changes in brain areas involved in emotional processing in depression. Neuropsychopharmacol. 2016;41(2): 487-97. https://doi.org/10.1038/npp.2015.170.

10. Brandt J, Warnke K, Jörgens S, Arolt V, Beer K, Domschke K, et al. Association of FKBP5 genotype with depressive symptoms in patients with coronary heart disease: a prospective study. J Neural Transm. 2020;127(12):1651-62. https://doi.org/10.1007/s00702-020-02243-6.

11. Lekman M, Laje G, Charney D, Rush AJ, Wilson AF, Sorant AJ, et al. The FKBP5-gene in depression and treatment response--an association study in the sequenced treatment alternatives to relieve depression (STAR*D) cohort. Biol Psychiatry. 2008;63(12):1103-10. https://doi.org/10.1016/j.biopsych.2 007.10.026.

12. Zimmermann $P$, Bruckl T, Nocon A, Pfister $H$, Binder EB, Uhr M, et al. Interaction of FKBP5 gene variants and adverse life events in predicting depression onset: results from a 10-year prospective community study. Am J Psychiatry. 2011;168(10):1107-16. https://doi.org/10.1176/appi.ajp.2011.1 0111577.

13. Piechaczek CE, Greimel E, Feldmann L, Pehl V, Allgaier AK, Frey M, et al. Interactions between FKBP5 variation and environmental stressors in adolescent major depression. Psychoneuroendocrino. 2019;106:28-37. https://doi.org/10.1016/j.psyneuen.2019.03.025.

14. Shimasaki A, Kondo K, Saito T, Esaki K, Otsuka Y, Mano K, et al. A genetic variant in 12q13, a possible risk factor for bipolar disorder, is associated with depressive state, accounting for stressful life events. PLoS ONE. 2014;9(12): e115135. https://doi.org/10.1371/journal.pone.0115135.

15. Scheuer $S$, Ising $M$, Uhr M, Otto $Y$, von Klitzing K, Klein AM. FKBP5 polymorphisms moderate the influence of adverse life events on the risk of anxiety and depressive disorders in preschool children. J Psychiatr Res. 2016; 72:30-6. https://doi.org/10.1016/j.jpsychires.2015.10.009. 
16. Jiang S, Postovit L, Cattaneo A, Binder EB, Aitchison KJ. Epigenetic modifications in stress response genes associated with childhood trauma. Front Psychiatry. 2019;10. https://doi.org/10.3389/fpsyt.2019.00808.

17. Alexander N, Kirschbaum C, Wankerl M, Stauch BJ, Stalder T, SteudteSchmiedgen $\mathrm{S}$, et al. Glucocorticoid receptor gene methylation moderates the association of childhood trauma and cortisol stress reactivity. Psychoneuroendocrino. 2018;90:68-75. https://doi.org/10.1016/j.psyneuen.2 018.01.020.

18. Zannas AS, Wiechmann T, Gassen NC, Binder EB. Gene-stress-epigenetic regulation of FKBP5: clinical and translational implications. Neuropsychopharmacol. 2016;41(1):261-74. https://doi.org/10.1038/npp.201 5.235 .

19. Corfield EC, Yang Y, Martin NG, Nyholt DR. A continuum of genetic liability for minor and major depression. Transl Psychiatry. 2017;7(5):e1131. https:// doi.org/10.1038/tp.2017.99.

20. Kang C, Shi J, Gong Y, Wei J, Zhang M, Ding H, et al. Interaction between FKBP5 polymorphisms and childhood trauma on depressive symptoms in Chinese adolescents: the moderating role of resilience. J Affect Disord. 2020; 266:143-50. https://doi.org/10.1016/j.jad.2020.01.051.

21. Klengel T, Binder EB. FKBP5 allele-specific epigenetic modification in gene by environment interaction. NEUROPSYCHOPHARMACOL. 2015;40(1):244-6. https://doi.org/10.1038/npp.2014.208.

22. Murphy DA, Brecht ML, Huang D, Herbeck DM. Trajectories of delinquency from age 14 to 23 in the National Longitudinal Survey of youth sample. Int J Adolesc Youth. 2012;17(1):47-62. https://doi.org/10.1080/02673843.2011.64 9401.

23. Lipps G, Lowe GA, Gibson RC, Halliday S, Morris A, Clarke N, et al. Parenting and depressive symptoms among adolescents in four Caribbean societies. Child Adolesc Psychiatry Ment Health. 2012;6(1):31. https://doi.org/10.1186/1 753-2000-6-31.

24. Griffith JM, Crawford CM, Oppenheimer CW, Young JF, Hankin BL. Parenting and youth onset of depression across three years: examining the influence of observed parenting on child and adolescent depressive outcomes. J Abnorm Child Psychol. 2019;47(12):1969-80. https://doi.org/10.1007/s10802019-00564-z.

25. Wang W, Du X, Guo Y, Li W, Zhang S, Zhang W, et al. Associations among screen time, sleep duration and depressive symptoms among Chinese adolescents. J Affect Disord. 2021;284:69-74. https://doi.org/10.1016/j.jad.2 021.01.082.

26. Wang W, Du X, Guo Y, Li W, Teopiz KM, Shi J, et al. The associations between sleep situations and mental health among Chinese adolescents: a longitudinal study. Sleep Med. 2021;82:71-7. https://doi.org/10.1016/j.sleep.2 021.03.009.

27. Tollenaar MS, Molendijk ML, Penninx B, Milaneschi Y, Antypa N. The association of childhood maltreatment with depression and anxiety is not moderated by the oxytocin receptor gene. Eur Arch Psychiatry Clin Neurosci. 2017;267(6):517-26. https://doi.org/10.1007/s00406-017-0784-z.

28. Zobel A, Schuhmacher A, Jessen F, Hofels S, von Widdern O, Metten M, et al. DNA sequence variants of the FKBP5 gene are associated with unipolar depression. Int J Neuropsychopharmacol. 2010;13(5):649-60. https://doi.org/10.1017/S1461145709991155.

29. Lee SW, Stewart SM, Byrne BM, Wong JP, Ho SY, Lee PW, et al. Factor structure of the Center for Epidemiological Studies Depression Scale in Hong Kong adolescents. J Pers Assess. 2008;90(2):175-84. https://doi.org/1 0.1080/00223890701845385.

30. Zhi-yan C, Xiao-dong Y. Psychometric Features of CES-D in Chinese Adolescents (in Chinese). Chinese J Clin Psychol. 2009;17(4):443-445.

31. Radloff LS. The use of the Center for Epidemiologic Studies Depression Scale in adolescents and young adults. J Youth Adolesc. 1991;20(2):149-66. https://doi.org/10.1007/BF01537606.

32. YANG H. Using the CES-D in a two-phase survey for depressive disorders among nonreferred adolescents in Taipei: a stratum-specific likelihood ratio analysis. J Affect Disord 2004, https://doi.org/10.1016/j.jad.2004.04.008.

33. Guo L, Xu Y, Deng J, Huang J, Huang G, Gao X, et al. Association between sleep duration, suicidal ideation, and suicidal attempts among Chinese adolescents: the moderating role of depressive symptoms. J Affect Disord. 2017;208:355-62. https://doi.org/10.1016/j.jad.2016.10.004.

34. Baumrind D. Patterns of parental authority and adolescent autonomy. New Dir Child Adolesc Dev. 2005;108(108):61-9. https://doi.org/10.1002/cd.128.
35. Baumrind D. The influence of parenting style on adolescent competence and substance use. J Early Adolesc. 1991;11(1):56-95. https://doi.org/10.11 77/0272431691111004

36. Coolen MW, Statham AL, Gardiner-Garden M, Clark SJ. Genomic profiling of CpG methylation and allelic specificity using quantitative high-throughput mass spectrometry: critical evaluation and improvements. Nucleic Acids Res. 2007;35(18):e119. https://doi.org/10.1093/nar/gkm662.

37. Okada S, Morinobu S, Fuchikami M, Segawa M, Yokomaku K, Kataoka T, et al. The potential of SLC6A4 gene methylation analysis for the diagnosis and treatment of major depression. J Psychiatr Res. 2014;53:47-53. https:// doi.org/10.1016/j.jpsychires.2014.02.002.

38. Lam D, Ancelin ML, Ritchie K, Freak-Poli R, Saffery R, Ryan J. Genotypedependent associations between serotonin transporter gene (SLC6A4) DNA methylation and late-life depression. BMC Psychiatry. 2018;18(1):282. https:// doi.org/10.1186/s12888-018-1850-4.

39. Benjamini Y, Drai D, Elmer G, Kafkafi N, Golani I. Controlling the false discovery rate in behavior genetics research. Behav Brain Res. 2001;125(1-2): 279-84. https://doi.org/10.1016/S0166-4328(01)00297-2.

40. Lou QY, Li Z, Teng Y, Xie QM, Zhang M, Huang SW, et al. Associations of FKBP4 and FKBP5 gene polymorphisms with disease susceptibility, glucocorticoid efficacy, anxiety, depression, and health-related quality of life in systemic lupus erythematosus patients. Clin Rheumatol. 2021;40(1):16779. https://doi.org/10.1007/s10067-020-05195-0.

41. Wang H, Wang C, Song X, Liu H, Zhang Y, Jiang P. Association of FKBP5 polymorphisms with patient susceptibility to coronary artery disease comorbid with depression. PEERJ. 2020;8:e9286. https://doi.org/10.7717/ peerj.9286.

42. Gorostiaga A, Aliri J, Balluerka N, Lameirinhas J. Parenting Styles and Internalizing Symptoms in Adolescence: A Systematic Literature Review. Int J Environ Res Public Health. 2019;16(17):16(17). https://doi.org/10.3390/ ijerph16173192.

43. Colodro-Conde L, Couvy-Duchesne B, Zhu G, Coventry WL, Byrne EM, Gordon S, et al. A direct test of the diathesis-stress model for depression. Mol Psychiatry. 2018;23(7):1590-6. https://doi.org/10.1038/mp.2017.130.

44. Han KM, Won E, Sim Y, Kang J, Han C, Kim YK, et al. Influence of FKBP5 polymorphism and DNA methylation on structural changes of the brain in major depressive disorder. Sci Rep. 2017;7(1):42621. https://doi.org/10.1038/ srep42621.

45. Klinger-Konig J, Hertel J, Van der Auwera S, Frenzel S, Pfeiffer L, Waldenberger $\mathrm{M}$, et al. Methylation of the FKBP5 gene in association with FKBP5 genotypes, childhood maltreatment and depression. Neuropsychopharmacol. 2019;44(5):930-8. https://doi.org/10.1038/s41386-01 9-0319-6.

46. Hohne N, Poidinger M, Merz F, Pfister H, Bruckl T, Zimmermann P, et al. FKBP5 genotype-dependent DNA methylation and mRNA regulation after psychosocial stress in remitted depression and healthy controls. Int J Neuropsychoph. 2015;18(4):u87. https://doi.org/10.1093/ijnp/pyu087.

47. Bustamante AC, Aiello AE, Guffanti G, Galea S, Wildman DE, Uddin M. FKBP5 DNA methylation does not mediate the association between childhood maltreatment and depression symptom severity in the Detroit neighborhood health study. J Psychiatr Res. 2018;96:39-48. https://doi.org/1 0.1016/j.jpsychires.2017.09.016.

\section{Publisher's Note}

Springer Nature remains neutral with regard to jurisdictional claims in published maps and institutional affiliations.

Ready to submit your research? Choose BMC and benefit from:

- fast, convenient online submission

- thorough peer review by experienced researchers in your field

- rapid publication on acceptance

- support for research data, including large and complex data types

- gold Open Access which fosters wider collaboration and increased citations

- maximum visibility for your research: over $100 \mathrm{M}$ website views per year

At BMC, research is always in progress.

Learn more biomedcentral.com/submissions 